\title{
Age, Sr- and Nd-Isotope Systematics, and Origin of Two Fluorite Lodes, Sierras Pampeanas, Argentina ${ }^{1}$
}

\author{
C. Galindo, \\ Departamento Petrología y Geoquímica, Facultad Geología, Universidad Complutense de Madrid, 28.040 Madrid, Spain \\ R. J. PANKHURST, \\ British Antarctic Survey, c/o NIGL, Keyworth, Nottingham, NG12 5GG, United Kingdom \\ C. CAsquet, \\ Departamento Petrología y Geoquimica, Facultad Geología, Universidad Complutense de Madrid, 28.040 Madrid, Spain \\ J. Coniglio, \\ Departamento de Geología, Universidad Nacional de Rio Cuarto, 5800 Rio Cuarto, Argentina \\ E. BALDO, \\ Departamento de Geología Básica, CONICET/Universidad Nacional de Córdoba, 5000 Córdoba, Argentina \\ C. W. RAPELA, \\ Centro de Investigaciones Geológicas, CONICET/Universidad Nacional de La Plata, 1900 La Plata, Argentina \\ AND J. SAAVEDRA, \\ Instituto de Recursos Naturales y Agrobiología, CSIC, 37080 Salamanca, Spain
}

\begin{abstract}
Fluorite mineralization at the La Nueva and Bubu mines yields Sm-Nd ages of $131 \pm 22$ and $117 \pm 26 \mathrm{Ma}$, respectively. Thus, the mineralization most probably is related to a late Gondwanian (Lower Cretaceous) extensional and magmatic event that affected the Sierras Pampeanas basement during the opening of the Atlantic Ocean. Hydrothermal fluids involved in the formation of the fluorite probably were of meteoric origin, their isotopic composition ( $\mathrm{Sr}$ and $\mathrm{Nd}$ ) resulting largely from the incongruent dissolution of feldspars in the host porphyritic granites.
\end{abstract}

\section{Introduction}

The Sierras Pampeanas are blocks of preAndean basement exposed in central and northwestern Argentina. They consist of Paleozoic granitoids and medium- to high-grade metamorphic rocks, mostly schists and gneisses, that supposedly are of Upper Precambrian to Lower Paleozoic age (Linares and Latorre, 1969; Cingolani and Varela, 1975).

Fluorite veins of economic interest are relatively common in the Sierras Pampeanas west

'This paper is one of a series of contributions (Marcos Zentilli, compiler) to Project No. 342, Age and Isotopes of South American Ores, of the International Geological Correlation Program. and south of the city of Córdoba; in some cases they are being mined at present. Despite previous studies of the geology and mineralogy of these lodes, uncertainties remain concerning their age and the source of the ore-forming hydrothermal fluids. The suggested ages range from Late Paleozoic-i.e., possibly related to the host granitoids (Angeleli et al., 1980)-to Late Tertiary (González Díaz, 1972).

The recent application of Sm-Nd systematics to the study of fluorite in hydrothermal veins, when combined with Sr-isotope geochemistry, represents a powerful technique for determining the age of the mineralization and for constraining the source and subsequent history of the mineralizing fluids involved (Halliday et al., 


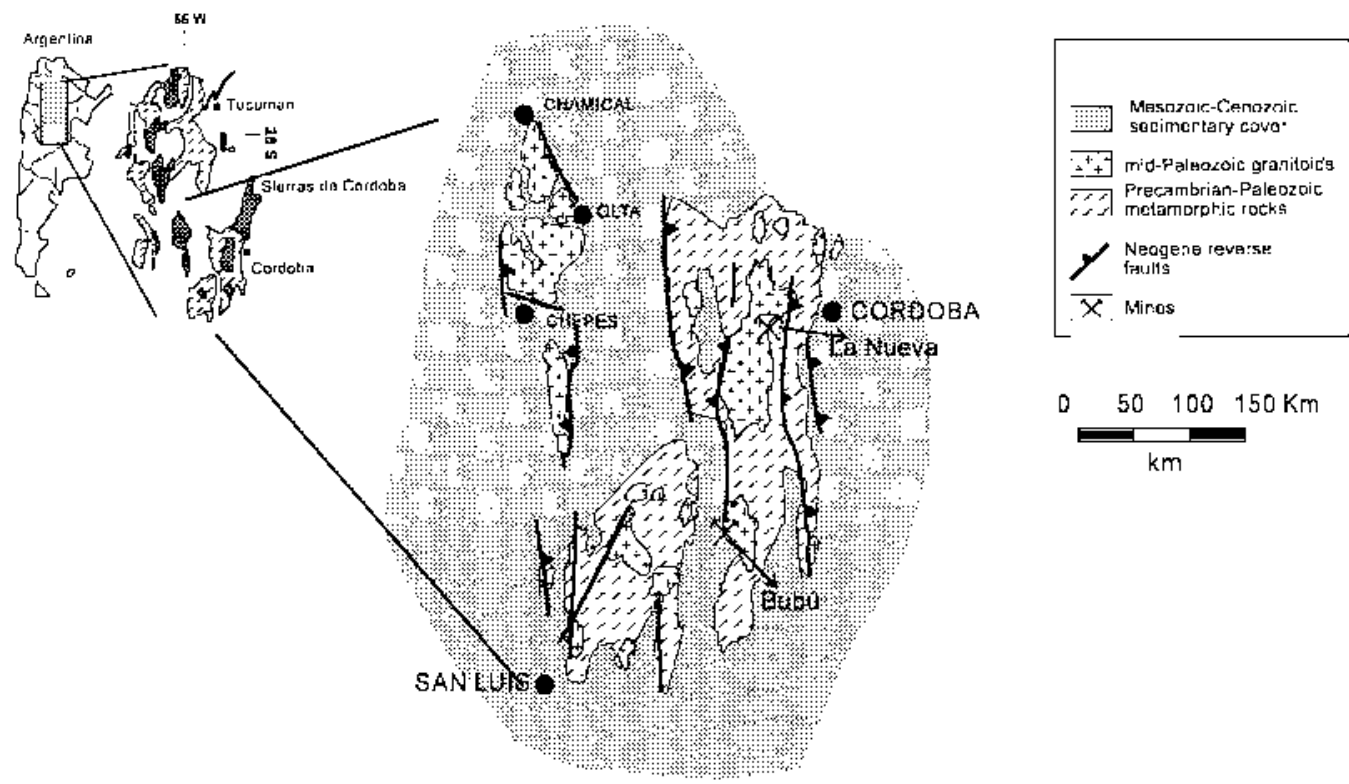

Fig. 1. Geological sketch map of the Sierras Pampeanas, showing the location of the two mines studied.

1986, 1990; Darbyshire and Shepherd, 1990; Chesley et al., 1991; Galindo et al., 1994; Höhndorf et al., 1994; Nagler et al., 1995). In this paper we provide Sm.Yd ages of fluorites from two sites in Córdoba province-La Nueva mine $\left(31^{\circ} 27^{\prime} \mathrm{S}, 64^{\circ} 36^{\prime} \mathrm{W}\right), \sim 14 \mathrm{~km}$ west of Villa Carlos Paz, and Bubu mine $\left(32^{\circ} 36^{\prime} \mathrm{S}\right.$, $\left.64^{\circ} 57^{\circ} \mathrm{W}\right)$, in the Sierra de Comechingones (Fig. 1).

\section{Geological Setting}

The Ia Nueva mine is located near the border of the large 5-type granitic batholith of Achala. Veins occur on both sides of the granitoid contact with the metamorphic rocks. The Bubu mine is located within the broadly comparable Cerro Aspero batholith, not far from its southeastern contact with the metamorphic envelope (Fig. l).

The Achala and Cerro Aspero batholiths belong to the G2 group of granitoids of the Sierras Pampeanas, which are middle Paleozoic in age (Rapela et al., 1992). A whole-rock Rb-Sr isochron age of $358 \pm 9 \mathrm{Ma}$, i.e., Late Devo. nian-Early Carboniferous, was obtained for part of the Achala batholith by Rapela et al. (1991). Porphyritic biotite ( \pm muscovite) monzogranites are the main petrographic type, followed in importance by two-mica leucogranites (Rapela et al., 1992). These granitoids have high contents of large-ion lithophile elements, as well as of $\mathrm{P}$ and Ti. Initial ${ }^{87} \mathrm{Sr} /{ }^{66} \mathrm{Sr}$ ratios also are high (typically $>0.712$ ), suggesting derivation of the magmas by crustal anatexis. W and U hydrothermal deposits and complex pegmatites rich in $\mathrm{Li}, \mathrm{Be}, \mathrm{Nb}, \mathrm{Ta}$, and $\mathrm{L}$ are common within these batholiths.

Fluorite is a rare accessory mineral in the monzogranites, as well as in association with beryl in greisenized zones in the two-mica leucogranites. It also is a gangue mineral in high-temperature wolframite veins. However, most of the fluorite in the area of the Achala and Cerro Aspero batholiths is in discordant veins, which often are located close to the contacts with the enclosing metamorphic rocks. On a regional scale, the fluorite veins are the easternmost manifestation of a $\sim 4.00 \mathrm{~km}$ wide belt of fluorite deposits that extends westward to the boundary of the Andes and that is related to first-order tectonic lineaments (Magliola Mundet, 1990). The mines studied in this paper form part of the Larca-Bubu metallogenic subdistrict, which is a part of the larger Sierras Pampeanas-Precordillera district (Menoyo and Brodtkorb, 1975).

The fluorite veins form an en echelon swarm, with trends close to $\mathrm{N} 100^{\circ} \mathrm{E}$ and dips of $70^{\circ} \mathrm{N}$ 


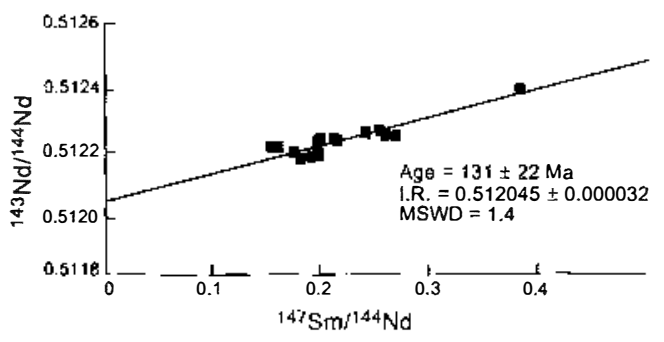

B

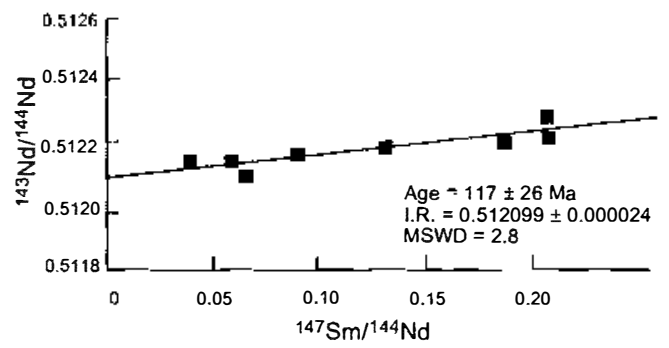

Fic. 2. Sm-Nd isochrons from fluorites. A. La Nueva mine. B. Bubu mine.

at La Nueva, whereas at Bubu the veins are subvertical with a dominant direction of $\mathrm{N} 35^{\circ}$ to $50^{\circ} \mathbf{E}$ (Fig. 2). The thickness of the veins is variable, but usually is $<2 \mathrm{~m}$; length along strike ranges from a few meters to several hundred meters. The main veins often branch off into smaller subparallel veins. The septa between veins consist of strongly brecciated host rocks that show interse silicification.

The veins consist of banded fluorite and chalcedony. Some pyrite (either older or younger than fluorite) in late fractures and traces of U-minerals also can be found. The fluorite is fibrous to columnar (with the long axis perpendicular to the banding) or sometimes cubic. Individual layers of fluorite are 1 $\mathrm{mm}$ to $10 \mathrm{~cm}$ thick and display a remarkable color variation-black; light and dark purple; and, to a lesser extent, amber, green, and colorless. At La Nueva, precipitation would appear to be from black $\rightarrow$ purple $\rightarrow$ yellow. The position of the green fluorite is not obvious. Repeated zonation often is found, suggesting that infilling of the fractures occurred in pulses.

The fluorite lodes were formed at shallow depths $(<2 \mathrm{~km})$ and at temperatures of $215^{\circ}$ to $300^{\circ} \mathrm{C}$ (Coniglio, 1992). These conditions are common elsewhere in fluorite veins of the unconformity-related type (Dill and Nielsen, 1987; Rowan et al., 1996).

\section{Isotope Geochemistry}

Fluorite samples of different colors from the two mines were analyzed for isotopic composition ( $\mathrm{Sr}$ and $\mathrm{Nd}$, and $\mathrm{Sm} / \mathrm{Nd}$ ratio) by massspectrometric isotope dilution. The analytical methods and data-reduction issues involved are described in Galindo et al. (1994). In some cases, samples were taken from different-colored bands in the same hand specimen. In total, 16 samples were analyzed from La Nueva and 8 from Bubu (Table 1). In three samples from La Nueva, Rb and $\mathrm{Sr}$ also were determined; all the samples have low ${ }^{87 \mathrm{Rb} /}{ }^{86} \mathrm{Sr}$ ratios $(0.007$ to $0.036)$, indicating that only a small age correction was necessary to obtain the initial ${ }^{87} \mathrm{Rb} /{ }^{86} \mathrm{Sr}$ ratio from the measured ratio. The rest of the samples were corrected using a value of 0.02 that was assumed for this purpose. Errors ( $2 \sigma$ level) are assumed to be $0.1 \%$ in Sm/ $\mathrm{Nd}$ and $0.006 \%$ in ${ }^{143} \mathrm{Nd} /{ }^{144} \mathrm{Nd}$ ratios.

$\mathrm{Sm}-\mathrm{Nd}$ isochron plots are shown in Figure 2. For La Nueva, the ${ }^{1 / 7} \mathrm{Sm} /{ }^{44} \mathrm{Nd}$ ratio varies from 0.154 to 0.385 , and the data points define an isochron (MSWD = 1.4) with an age of $131 \pm$ $22 \mathrm{Ma}$ and an initial ${ }^{143} \mathrm{Nd} /{ }^{144} \mathrm{Nd}$ ratio of $0.51204 \pm 0.00003$. The corresponding $\epsilon \mathrm{Nd}$ values at $130 \mathrm{Ma}$ are -7.8 to -8.8 . Initial ${ }^{87} \mathrm{Sr} / 86 \mathrm{Sr}$ ratios vary from 0.722 to 0.727 and appear to fall into two groups with mean values close to 0.723 and 0.726 . This may reflect a color difference (the first group is mainly black and yellow, the second purple and green), but there is no comparable variation in $\mathrm{Nd}$. The results for the Bubu mine display more scatter and yield an isochron of $117 \pm 26 \mathrm{Ma}$ (MSWD = $2.8)$. The corresponding initial ${ }^{143} \mathrm{Nd} /{ }^{144} \mathrm{Nd}$ ratio is $0.51210 \pm 0.00002$, and $\epsilon \mathrm{Nd}_{\text {, values }}$ range from -7.0 to -8.3 . The spread of ${ }^{147} \mathrm{Sm} /{ }^{14} \mathrm{Nd}(0.042$ to 0.204$)$ is less than at $\mathrm{La}$ Nueva. If the two sets of Sm-Nd data are combined, the result (MSWD $=3.6$ ) is $104 \pm 13 \mathrm{Ma}$. The $\mathrm{Sr}$-isotope composition also is distinctively less radiogenic than at La Nueva $\left({ }^{87} \mathrm{Sr} /{ }^{86} \mathrm{Sr}=\right.$ 0.717 to 0.722 , with most values near 0.721 ). 
TABLE 1. Rb/Sr and Sm/Nd Data of Fluorites from La Nueva and Bubu Mines

\begin{tabular}{|c|c|c|c|c|c|c|c|c|c|c|c|c|c|c|}
\hline Sample & Sm, ppm & Nd, ppm & ${ }^{147} \mathrm{Sm} /{ }^{14} \mathrm{Nd}$ & $\%$ s.d. & ${ }^{1} \mathrm{~N} \mathrm{Nd} /{ }^{1} \mathrm{Nd}$ & $\%$ s.d. & ${ }^{143} \mathrm{Nd} /{ }^{14} \mathrm{Nd}$ & $\epsilon \mathrm{Nd}_{131}$ & $\mathrm{Rb}$, ppm & $\mathrm{Sr}, \mathrm{ppm}$ & ${ }^{\mathrm{A}} \mathrm{Rb} /{ }^{805 \mathrm{~S}}$ & ${ }^{87} \mathrm{Sr} /{ }^{86} \mathrm{Sr}$ & ${ }^{87} \mathrm{Sr} /{ }^{\circ 6} \mathrm{Sr}_{131}$ & $E S r_{\text {เy }}$ \\
\hline \multicolumn{15}{|c|}{ La Nueva mine } \\
\hline $175 . \mathrm{Jb}$ & 1.708 & 6.705 & 0.1540 & 0.1 & 0.512201 & 0.003 & 0.512069 & -7.9 & & & 0.020 & 0.723520 & 0.723483 & 272 \\
\hline $176.2 b$ & 1.642 & 6.184 & 0.1605 & 0.1 & $0.5122 \mathrm{l}$ & 0.003 & 0.512073 & -7.8 & & & 0.020 & 0.722321 & 0.722284 & 255 \\
\hline $177-1 y$ & 5.506 & 8.651 & 0.3847 & 0.1 & 0.512394 & 0.003 & 0.512064 & -7.9 & 0.22 & 52.0 & 0.013 & 0.726406 & 0.726383 & 313 \\
\hline $178-2 y$ & 3.128 & 8.943 & 0.2114 & 0.1 & 0.512239 & 0.003 & 0.512058 & -8.1 & & & 0.020 & 0.72268 & 0.722644 & 260 \\
\hline $179-3 y$ & 1.553 & 4.730 & 0.1985 & 0.1 & 0.512228 & 0.003 & 0.512058 & -8.1 & & & 0.020 & 0.723357 & 0.723320 & 269 \\
\hline $180-\mathrm{lc}$ & 3.589 & 8.076 & 0.2686 & 0.1 & 0.512251 & 0.003 & 0.512021 & -8.8 & & & 0.020 & 0.723300 & 0.723263 & 269 \\
\hline $181-2 c$ & 1.516 & 4.800 & 0.1909 & 0.1 & 0.512185 & 0.003 & 0.512021 & -8.8 & 0.12 & 50.5 & 0.007 & 0.726303 & 0.726291 & 312 \\
\hline $182-\lg$ & 8.240 & 25.087 & 0.1985 & 0.1 & 0.512203 & 0.003 & 0.512033 & -8.6 & 0.93 & 77.3 & 0.036 & 0.726765 & 0.726698 & 317 \\
\hline $183-2 \mathrm{~g}$ & 8.329 & 25.618 & 0.1965 & 0.1 & 0.512205 & 0.003 & 0.512037 & -8.5 & & & 0.020 & 0.726371 & 0.726334 & 312 \\
\hline 184-lp & 4.444 & 11.153 & 0.2409 & 0.1 & 0.512259 & 0.003 & 0.512053 & -8.2 & & & 0.020 & 0.726848 & 0.726811 & 319 \\
\hline $185.2 p$ & 8.491 & 23.916 & 0.2146 & 0.1 & 0.512236 & 0.003 & 0.512052 & -8.2 & & & 0.020 & 0.726462 & 0.726425 & 313 \\
\hline LN3-1 & 1.448 & 4.855 & 0.1803 & 0.1 & 0.512174 & 0.003 & 0.512019 & -8.8 & & & 0.020 & 0.724156 & 0.724119 & 281 \\
\hline L.N3-2 & 1.741 & 6.047 & 0.1740 & 0.1 & 0.512198 & 0.003 & 0.512049 & -8.2 & & & 0.020 & 0.725304 & 0.725267 & 297 \\
\hline LN3-3 & 0.961 & 2.249 & 0.2583 & 0.1 & 0.512250 & 0.003 & 0.512029 & -8.6 & & & 0.020 & 0.725836 & 0.725799 & 305 \\
\hline LN3-6 & 3.040 & 7.247 & 0.2536 & 0.1 & 0.512267 & 0.003 & 0.512050 & -8.2 & & & 0.020 & 0.726574 & 0.726537 & 315 \\
\hline LN4.] & 9.657 & 29.645 & 0.1969 & 0.1 & 0.512211 & 0.003 & 0.512042 & -8.4 & & & 0.020 & 0.726617 & 0.726580 & 316 \\
\hline \multicolumn{15}{|c|}{ Bubu mine } \\
\hline $1 \cdot c$ & 0.510 & 4.786 & 0.0644 & 0.1 & 0.512111 & 0.003 & 0.512062 & -8.3 & & & 0.020 & 0.720016 & 0.7199827 & 222 \\
\hline $2-1 y$ & 0.069 & 0.993 & 0.0422 & 0.1 & 0.512150 & 0.003 & 0.512118 & -7.3 & & & 0.020 & 0.720913 & 0.7208797 & 235 \\
\hline $3-2 y$ & 0.223 & 2.338 & 0.0577 & 0.1 & 0.512153 & 0.003 & 0.512109 & -7.4 & & & 0.020 & 0.720916 & 0.7208827 & 235 \\
\hline $4-g$ & 13.671 & 40.483 & 0.2041 & 0.1 & 0.512247 & 0.003 & 0.512091 & -7.8 & & & 0.020 & 0.720615 & 0.7205817 & 230 \\
\hline $5-w$ & 1.034 & 3.383 & 0.1847 & 0.1 & 0.512211 & 0.003 & 0.512070 & -8.2 & & & 0.020 & 0.722 L.30 & 0.7220967 & 252 \\
\hline $6-1 p$ & 0.107 & 0.317 & 0.2036 & 0.1 & 0.512288 & 0.003 & 0.512132 & -7.0 & & & 0.020 & 0.716807 & 0.7167737 & 176 \\
\hline $7-r$ & 1.768 & 12.163 & 0.0879 & 0.1 & 0.512174 & 0.003 & 0.512107 & -7.5 & & & 0.020 & 0.720925 & 0.7208917 & 235 \\
\hline $8-2 p$ & 3.544 & 16.542 & 0.1295 & 0.1 & 0.512208 & 0.003 & 0.512109 & 7.4 & & & 0.020 & 0.720909 & 0.7208757 & 234 \\
\hline
\end{tabular}

'Lowercase letters in sample designalions refer to fluorite colors: $b=$ black; $y=$ yellow; $c=$ colorless; $g=g r e e n ; p=p u r p l e ; w=u$ hite; $r=$ pink. 

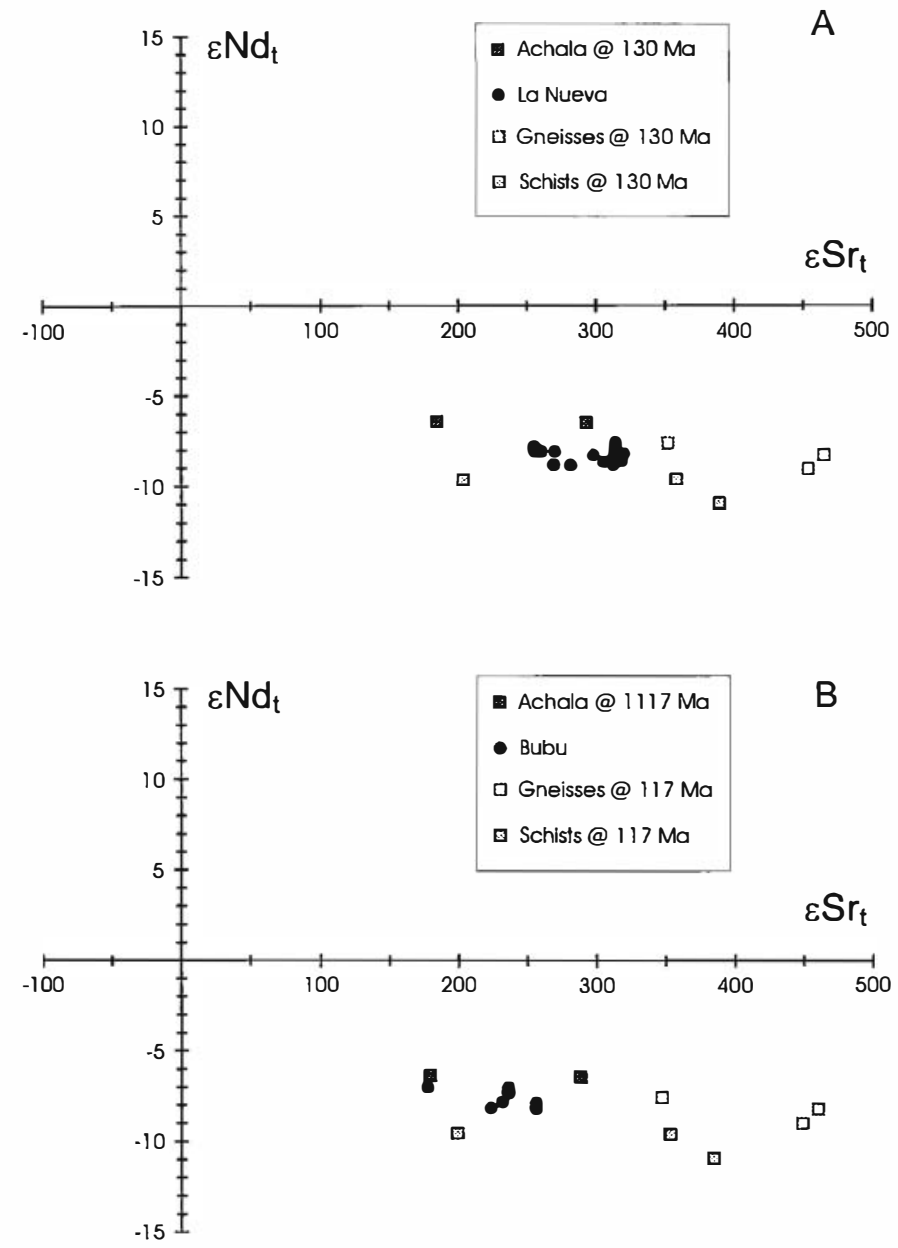

FIC. 3. $\epsilon \mathrm{Nd}_{1}-\epsilon \mathrm{Sr}_{1}$ plots of fluorites and regional rocks: Achala porphyritic monzogranites and metamorphic rocks (unpubl. data). A. La Nueva mine. B. Bubu mine.

\section{Discussion and Conclusions}

The isochron relationships obtained do not result in very precise ages because of the small range of ${ }^{143} \mathrm{Nd} /{ }^{144} \mathrm{Nd}$ ratios. Nevertheless, the similarity of the two results indicates that they record a formation event that was almost certainly Early Cretaceous in age-within the limits of error the stratigraphic range is Upper Jurassic to Middle Cretaceous. This rules out the possibility of any genetic association with the magmatic stage of the Achala and Cerro Aspero batholiths, which host the lodes.

However, Early Cretaceous emplacement is readily related to brittle deformation of the basement rocks of the Sierras Pampeanas under regional extensional conditions (e.g., Ciciarelli,
1984). Concomitant eruption of alkali basalt took place along the La Punilla and La Calera faults (Kay and Ramos, 1996). K-Ar ages of 112 $\pm 6 \mathrm{Ma}$ and $128 \pm 5 \mathrm{Ma}$ have been quoted for this volcanism in the Sierra de los Condores and Pungo area (Gordillo and Lencinas, 1976). Similarly, K-Ar ages from $120 \pm 2 \mathrm{Ma}$ to $130 \pm 6 \mathrm{Ma}$ are recorded by Gonzalez and Kawashita (1972), in the area south of Los Condores and Almafuerte. Trachybasalt dikes with equivalent $\mathrm{K}-\mathrm{Ar}$ ages also have been recognized by Stipanicic and Linares (1975), and it is noteworthy that these follow trends that are similar to those of the fluorite veins. The thermal anomaly represented by the alkali volcanism could well have resulted in high-level convec- 
tive circulation of the hot $\left(>300^{\circ} \mathrm{C}\right)$ hydrothermal fluids that deposited the fluorites. This Mesozoic tectonothermal event also can be correlated with the Argentinian late-Gondwanic event defined by Rapela and Llambias (1997).

Isotope geochemistry may be used to constrain the source of $\mathrm{Sr}$ and $\mathrm{Nd}$ in the hydrothermal fluids. The Nd-isotope composition of the fluorites at the time of formation (Table 1) is quite similar in both mines $(\epsilon \mathrm{Nd}=-7.4$ to -8.8 at La Nueva, and -7.4 to -8.3 at Bubu), and is less radiogenic than that of the Achala porphyritic granites at the same age (two available samples of the latter yieid $\epsilon \mathrm{Nd}_{130}$ values of -6.5 and -6.9 [unpubl. data]). This suggests that a source of neodymium other than the granites was involved. In this respect, most available $\epsilon \mathrm{Nd}_{130}$ signatures of metamorphic rocks from different areas of the Sierras de Córdoba (unpubl. data) are lower than -9 , with a mean value at $\sim-10$ (Fig. 3 ). However, the ${ }^{87} \mathrm{Sr} / 86 \mathrm{Sr}$ composition of the fluorites is almost bracketed by that of the porphyritic granites $(\epsilon \mathrm{Sr}=176$ to 317 and 151 to 291, respectively), whereas the metamorphic rocks generally display $\epsilon \mathrm{Sr}_{130}$ values higher than 350 (Fig. 3). This suggests that most of the $\mathrm{Sr}$ in the fluid was contributed by the granites and is supported by evidence of pervasive hydrothermal alteration found at the selvages of the veins.

On a $\epsilon$ Nd- $\epsilon$ Sr diagram (Fig. 3), fluorites plot between the porphyritic granitoids and the metamorphic rocks from different areas of the Sierras de Córdoba (unpubl. data), suggesting that the isotopic composition of the fluorites might be explained by the mixing of a granitic and a metamorphic component in the fluid. However, a more realistic interpretation arises if fluid/rock interaction is considered in terms of whole-rock-fluid disequilibrium, i.e., if the dissolution behavior of the host-rock minerals during the hydrothermal alteration is taken into account (Galindo et al., 1994). The incongruent dissolution of feldspars during phyllic altcration (quartz + sericite + chlorite) probably is the main process controlling the isotopic composition of the circulating hot fluid. As these minerals contain most of the $\mathrm{Sr}$ in the rocks, the composition of the circulating hydrothermal fluid will be progressively modified to match that of the granite. The low $\mathrm{Sm} / \mathrm{Nd}$ ratios of feldspars relative to accessory minerals such as apatite, zircon, and sphene (Hanson, 1980), along with mass-balance considerations, could explain the low $\epsilon \mathrm{Nd}$ values of the fluorites relative to those of the granites. Most of the rare-earth elements contained in accessory minerals and biotite probably are retained despite chloritization (Alderton et al., 1980) and therefore do not contribute to a large extent to the fluid composition. This also can explain the homogeneity of the initial ${ }^{143} \mathrm{Nd} /{ }^{144} \mathrm{Nd}$ suggested by the isochrons. The slight differences in isotopic composition between deposits located in the two mines, especially in initial ${ }^{87} \mathrm{Sr} /{ }^{86} \mathrm{Sr}$ ratios, could indicate that they were formed from discrete highlevel convection systems with locally controlled compositions.

There is no direct evidence indicating the ultimate source of the fluids prior to their highlevel equilibration. The fluids could have been derived from water of mantle origin associated with the Cretaceous alkali volcanism or, perhaps more likely, they may have formed from meteoric water that percolated into tle circulating system or convection cell.

\section{Acknowledgments}

This work was supported by European Community Project No. CI*-CT92-0088 on "The Palaeozoic Evolution of the Andean Lithosphere $\left(30-32^{\circ} \mathrm{S}\right)$ and its Relation to Metalliferous Mineralizations" and by IGCP Project No. 342 on the "Age and Isotopes of South American Ores." Isotopic data were obtained at the National Isotope Geosciences Laboratory at Keyworth (UK). Critical reviews of this manuscript by Joaquin Ruiz and Daniel J. Kontak greatly improved the presentation of our results.

\section{REFERENCES}

Aiderton, D. M. H., Pearce, J. A., and Potts, P. J., 1980, Rare earth element mobility during granite alteration: Evidence from southwest England: Earth Planet. Sci. Lell., v. 49, p. 149-165.

Angeleli, V., Schalamuk, I., and Fernández, R., 1980, Los yacimientos de minerales no metalíferos y rocas de aplicación de la región Centro-Cuyo: Anales del Serv. Minero Nac., v. XIX, 145 p.

Chesley, J. T., Ha)liday, A. N., and Scrivener, R. C., 1991, Samarium-neodymium direct dating of fluorite mineralization: Science, v. 252, p. 949-951. 
Ciciarelli, M. I., 1984, Análisis estructural del sector oriental del Macizo Norpatagónico y su significado metalogenético: Unpubl. Ph.D. thesis, Univ. Nac. de La Plata, 179 p.

Cingolani, C. A., and Varela, R., 1975, Geocronología rubidio-estroncio de rocas ígneas y metamórficas de las Sierras Chica y Grande de Córdoba, República Argentina: II Congr. Ibero-Amer. Geol. Econ., v. l, p. 9-36.

Coniglio, J., 1992, Los yacimientos de fluorita en el batolito Cerro Aspero-Alpa Corral, Sa. de Comechingones, Córdoba, Argentina: IV Cong. Nac. Geol. Econ., Córdoba, Actas, p. 281-283.

Darbyshire, D. P. F., and Shepherd, T. J., 1990, Rb-Sr and $\mathrm{Sm}-\mathrm{Nd}$ constrains on the age of mineralization and the origin of hydrothermal fluids in SW England: Unpubl. paper presented at the 7th Int. Conf. Gcochronol. Cosmochronol. Isotope Geol., Canherra, A.C.T., Sept. 24-29.

Dill, H., and Nielsen, H., 1987, Geochronological and geochemical constrains on the formation of unconformity-rclated vein barite deposits of Central Europe: Jour. Geol. Soc. London, v. 144, p. 97-105.

Galindo, C., Tornos, F., Darbyshire, D. P. F., and Casquet, C., 1994, The age and origin of the baritefluorite $(\mathrm{Pb}-\mathrm{Zn})$ veins of the Sierra del Guadarrama (Spanish Central System, Spain): A radiogenic (Nd, $\mathrm{Sr}$ ) and stable-isotope study: Chem. Geol. (Isotope Geosci. Sect.), v. 112, p. 351-364.

Gonzalez, R., and Kawashita, K., 1972, Edades K-Ar de rocas básicas de la sierra de la provincia de Córdoba: Asoc. Geol. Argentina, v. 27, no. 2, p. 259-260.

González Díaz, E., 1972, Estudio geológico del Distrito Minero Cerro Aspero: Buenos Aires, Serv. Nac. Min. Geol. Anales, no. XVI, 55 p.

Gordillo, C., and Lencinas, A., 1976, Geología y petrología del extremo norte de la Sierra de Los Cóndores, Córdoba: Bol. Acad. Nac. Ciencias Argentina, v. 46, p. $73-108$.

Halliday, A. N., Shepherd, T. J., Dickin, A. P., MacLaren, F., and Darbyshire, D. P. F., 1986, Sm-Nd dating and fingerprinting of the north Pennine fluorite deposits [abs.]: Terra Cognita, v. 6, p. 2.

Halliday, A. N., Shepherd, T. J., Dickin, A. P., and Chesley, J. T., 1990, Sm-Nd evidence for the age and origin of Mississippi Valley-type deposits: Nature (London), v. 344, p. 54-56.

Hanson, G. N., 1980, Rare earth elements in petrogenetic studies of igneous systems: Ann. Rev. Earth. Planet. Sci., v. 8, p. 371-406.
Höhndorf, A., Kämpf, H., and Dulski, P., 1994, Sm/Nd and $\mathrm{Rb} / \mathrm{Sr}$ isotopic investigation on fluorite mineralization in the eastern Erzgebirge, in Seltman, R., Kámpr, H., and Möler, P., eds., Metallogeny of collisional orogens: Prague, Czech Geol. Surv., p. 116-128.

Kay, S. M., and Ramos, V. A., 1996, El magmatismo Cretácico de las Sierras de Córdoba y sus implicaciones tectónicas: XIII Cong. Geol. Argen., Actas, v. III, p. 453-464.

Linares, E., and Latorre, C. O., 1969, Edades K-Ar y plomo-alfa de rocas graníticas de las Provincias de Córdoba y San Luis: IV Cong. Geol. Argen., Actas, v. II, p. 195-204.

Magliola Mundet, H. . 1990, Regmagénesis y mineralizaciones de fluorita de la región Centro-Cuyo (Argen. tina): XI Cong. Geol. Argen., v. 1, p. 439-444.

Menoyo, E. A., and Brodtkorb, A., 1975, Fluorita y siderurgia Argentina: II Cong. Ibero-Amer. Geol. Econ., v. III, p. 235258.

Nagler, Th. F., Peltke, T, and Marshall, D., 1995, Initjal isotopic heterogencity and secondary disturbance of the Sm-Nd system in fluorites and fluid inclusions: A study on mesothermal veins from the central and western Swiss Alps: Chem. Geol. (Isotope Geosci. Sect.), v. 125, p. 24l-248.

Rapela, C. W., Pankhurst, R., Kirschbaum, A., and Baldo, E., 1991, Facies intrusivas de edad Carbónica en el Batolito de Achala: Evidencias de una anatexis regional en las Sierras Pampeanas?: VI Cong. Geol. Chileno, v. 1, p. 40-43.

Rapela, C. W., Coira, B., Toselli, A., and Saavedra, J., 1992, E] magmatismo del Paleozoico inlerior en el sudoeste de Gondwana, in Gutierrez Marco, J. C., Saavedra, J, and Ravano, I., eds., Paleozoico inferior de Iberoamérica: Mérida, Univ. Extremadura, p. $21-68$.

Rapela, C. W., and Llambias, E., 1997, El magmatismo Gondwánico y los ciclos fanerozoicos, in Camino, R., ed., Geología regional Argentina: Buenos Aires, Secretaría de Minería de la Nación (in press).

Rowan, E. L., Thiberioz, J., Bethke, C. M., and De Marsily, G., 1996, Geochemical and hydrologic conditions for fluorite mineralization in regions of continental extension: An example from the Albigeois district, France: El Paso, TX, Soc. Econ. Geol., Spec. Publ. 4.

Stipanicic, P., and Linares, E., 1975, Catálogos de edades radiométricas determinadas para la República Argentina I, años 1960-1974: Buenos Aires, Asoc. Geol. Argen., Spec. Publ. B3, p. 1-42. 